\title{
Effect of Wetting Agents upon Uptake by Sugarcane of Foliar-Applied Phosphorus ${ }^{1}$
}

\author{
J. Roldán-Regús, Luis H. Meyer, and Robert A. Luse ${ }^{2}$
}

\section{INTRODUCTION}

Crop fertilization by foliar application of nutrients has been widely studied and offers considerable promise for easy, economical correction of nutrient deficiencies in growing crops. Wetting agents, or surfactants, are frequently employed in the fertilizer formulation, with the aim of increasing foliar uptake. Since conflicting reports in the literature cite both reduced and increased phosphorus absorption, depending upon the wetting agent used, the $\mathrm{pH}$ of the applied solution, its concentration, and number and time of spray applications, it was our objective to measure the effect or some of these factors upon uptake by sugarcane of foliar applied phosphate, utilizing the radioactive isotope phosphorus ${ }^{32}$ as tracer.

\section{LITERATURE REVIEW}

Many investigators have studied the subject of foliar application of nutrients. Considerable increase in the yield and sugar content of sugar beets has been obtained in Russia by foliar application of potassium and phosphorus compounds $(16)^{3}$. Urea solutions applied as sprays to coffee, cacao, and bananas have benefitted these crops (10). In Germany deficiencies of zinc and strontium in Vitis vinifera and citrus have been corrected by means of foliar applications of these elements $(18,2)$. Sulfur and boron deficiencies in sugarcane and sugar beets have been corrected using foliar sprays $(13,15)$. In Louisiana and Hawaii foliar fertilization is commonly employed. Detailed studies have been carried on in Hawaii on the absorption and distribution in sugarcane of urea, $\mathrm{N}^{15}, \mathrm{P}^{32}, \mathrm{Rb}^{86}$ and labelled sucrose $(8,9)$.

Yung (21) has determined that phosphorus absorption is a first-order reaction and, in general, the absorption curves are logarithmic. Several authors report that the time required for 50-percent absorption of foliarapplied $\mathrm{P}^{32}$ is 15 days $(8,9,21)$. The reaction is modified by a series of

1 This study was carried out within the Agricultural Bio-Sciences Division of the Puerto Rico Nuclear Center, Rio Piedras, P.R., operated by the University of Puerto Rico for the U.S. Atomic Energy Commission.

${ }^{2}$ Chemist, Agricultural Experiment Station, Mayagüez Campus, University of Puerto Rico; Chemical Engineer, Trainee sponsored by the Organization of American States at the Puerto Rico Nuclear Center; Head, Agricultural Bio-Sciences Division, Puerto Rico Nuclear Center, respectively.

${ }^{3}$ Italic numbers in parentheses refer to Literature Cited, pp. 45-6. 
variables such as temperature, light, $\mathrm{pH}$ of the solution, wetting agents used, plant species, morphology of absorption organs, and nutritional status of the plant $(20,7,17)$. Colwell (11) has found evidence that, when more than 40 percent of the leaf is covered by the spray, the absorption values obtained are significant. Ahlgren (1) has shown that the primary leaves and the cotyledons are the plant parts which have the highest absorption rates.

The addition of certain wetting agents to fertilizer solutions has made possible greater absorption of the fertilizer by the plant $(3,4,5,6,12,14$, 19). These wetting agents are able to reduce the surface tension of the solutions, allowing them to spread as a thin film with high plant-surface contact. As a result, absorption is enhanced, with decrease in the leaching caused by rainfall.

We have not found evidence in the literature of any study on the influence of wetting agents upon the absorption of phosphate fertilizer applied as foliar spray to sugarcane in Puerto Rico. In view of the increasingly common local agronomic practice of aerial spray application of fertilizers, it was felt timely to conduct such studies. Utilization of the radioisotope $\mathrm{P}^{32}$ permits measurement of phosphorus absorption, leaching losses, and movement within the plant without error due to presence of phosphorus ${ }^{31}$ in the plant tissue.

\section{MATERIALS AND METHODS}

The extent of absorption of phosphorus applied to the sugarcane leaf was measured by applying the phosphate solution containing $\mathrm{P}^{32}$ to the leaf surface, then later rinsing the leaf and measuring the leached (nonabsorbed) phosphorus by the amount of radioactive tracer present in the rinse. Details of the method are as follows: Three-month-old sugarcane plants of variety P.R. 980 served as test plants. Phosphate solutions were tagged by addition of 0.1 microcurie $\mathrm{P}^{32}$ (as $\mathrm{H}_{3} \mathrm{P}^{32} \mathrm{O}_{4}$ solution in acid); 0.010 -ml. portions of these labelled phosphorus solutions were applied as six spots along the sides of the midrib and around the middle of the fourth leaf of each test plant. After a 1-hour period of absorption, during which time the plants were kept in the laboratory, the leaves were washed repeatedly, using as rinse $75 \mathrm{ml}$. of a 0.1-percent solution of ethylene diamine tetraacetic acid (disodium salt). The rinses were combined for each plant and taken to $100-\mathrm{ml}$. volume, from which a $2-\mathrm{ml}$. aliquot was taken and evaporated to dryness in a planchet. Counting for $\mathrm{P}^{32}$-content was done using a Geiger-Muller gas-flow detector with a thin end window operated in the proportional region. Phosphorus absorbed by the leaf was estimated from the difference in total radioactivity of the applied solution and that of the rinse. 
Experimental variables tested by this system included: 1, Type and concentration of wetting agent; $2, \mathrm{pH}$ of applied phosphorus solution; 3 , influence of cation upon phosphate absorption; and 4, the time course of $\mathrm{P}^{32}$ absorption by the sugarcane leaf. The wetting agents utilized and their commercial sources are listed in table 1 . The influence of $\mathrm{pH}$ on the absorption of phosphate supplied as the sodium, potassium, or ammonium salts was studied by using 0.1-M. phosphate solutions containing 0.1-percent anionic surfactant (Tergitol 7). Here absorption was let proceed for 24 hours. The rate of absorption was measured using $0.1-\mathrm{M} . \mathrm{KH}_{2} \mathrm{PO}_{4}$ solution, $\mathrm{pH} 3.0$, with 0.1 -percent concentration of three different wetting agents. The time required for uptake of 50 percent of the applied phosphorus was utilized in estimating these absorption rates.

TABLE 1.-Wetting agents tested

\begin{tabular}{l|c|c}
\hline \multicolumn{1}{c|}{ Commercial name } & Type & \multicolumn{1}{c}{ Supplier } \\
\cline { 1 - 2 } Tergitol 7 & Anionic & Union Carbide \\
Triton X-400 & Cationic & Rohm \& Haas \\
Agricultural surfactant No. 1 & Nonionic & Monsanto Chemical \\
Sterox AJ-100 & do. & Monsanto Chemical \\
Atlox 209 & do. & Atlas Chemical Industries \\
Atlox 210 & do. & Do. \\
Glycerine & Anionic & Fisher Scientific Co. \\
\hline
\end{tabular}

\section{RESULTS AND DISCUSSION}

The objectives of the first series of tests was to determine the optimum concentration of the wetting agent on the basis of the amount of foliar applied $\mathrm{P}^{32}$ absorbed by the plant. Reagent-grade phosphoric acid solution tagged with $\mathrm{P}^{32}$ and at a $\mathrm{pH}$ of 3 was the nutrient solution tested. This $\mathrm{pH}$ was considered optimum for our studies. Table 2 gives a summary of the results obtained. At a concentration of 0.1 percent all wetting agents enhanced the $\mathrm{P}^{32}$ absorption by the leaf of the sugarcane plant as compared with the control. The use of anionic-type Tergitol at concentrations of 0.01 or 0.1 percent caused the higest absorption of $\mathrm{P}^{32}$, while the use of the nonionic Atlox 209 at the same concentrations caused a repression in the absorption of $\mathrm{P}^{32}$ by the leaf. At a concentration of 0.001 percent, glycerine also caused a decrease in the absorption of phosphorus. At a concentration of 0.001 percent, Atlox 210 proved to be more effective than the other wetting agents tested.

The order of effectiveness of the various wetting agents is summarized in table 3 . When concentration of the wetting agents is plotted against extent of absorption of $\mathrm{P}^{32}$, the curves obtained indicate that absorption 
increases more or less linearly with logarithmic concentration of the wetting agent (fig. 1).

A series of tests was carried on to determine the $\mathrm{pH}$ range in which there occurred maximum absorption of foliar-applied orthophosphate

TABLE 2.-Effect of wetting agent and of concentration on absorption of foliar-applied $P^{32}$

\begin{tabular}{|c|c|c|}
\hline Wetting agent & $\begin{array}{l}\text { Concentration of wet- } \\
\text { ting agent, as percent }\end{array}$ & $\begin{array}{l}\text { Absorption of P32, as } \\
\text { percent applied }\end{array}$ \\
\hline Check $^{1}$ & - & 6.2 \\
\hline \multirow{3}{*}{ Anionic (Tergitol 7) } & 0.001 & 7.8 \\
\hline & .01 & 17.3 \\
\hline & .1 & 16.0 \\
\hline Check & 一 & 7.1 \\
\hline \multirow{3}{*}{ Cationic (Triton X-400) } & .001 & 7.5 \\
\hline & .01 & 9.7 \\
\hline & .1 & 12.3 \\
\hline Check & - & 6.2 \\
\hline \multirow{3}{*}{ Nonionic (Sterox AJ-100) } & .001 & 6.9 \\
\hline & .01 & 12.5 \\
\hline & .1 & 15.0 \\
\hline Check & - & 6.2 \\
\hline \multirow{3}{*}{ Nonionic (agricultural surfactant) } & .001 & 6.8 \\
\hline & .01 & 9.5 \\
\hline & .1 & 13.6 \\
\hline Check & - & 6.2 \\
\hline \multirow[t]{3}{*}{ Nonionic (Atlox 209) } & .001 & 3.7 \\
\hline & .01 & 4.5 \\
\hline & .1 & 11.1 \\
\hline Check & - & 7.1 \\
\hline \multirow{3}{*}{ Nonionic (Atlox 210) } & .001 & 10.2 \\
\hline & .01 & 10.9 \\
\hline & .1 & 13.6 \\
\hline Check & - & 7.1 \\
\hline \multirow[t]{3}{*}{ Glycerine } & .001 & 6.6 \\
\hline & .01 & 8.9 \\
\hline & .1 & 10.4 \\
\hline
\end{tabular}

${ }^{1}$ Water plus tagged solution of phosphoric acid.

salts. A 0.1-M. solution of the phosphate of sodium, potassium, or of ammonium, each containing 0.1 percent of Tergitol 7 , was applied to the fourth leaf of 3-month-old sugarcane plants. Twenty-four hours later the absorbed phosphorus was determined. The results in table 4 indicate that maximum absorption is indeed a function of the $\mathrm{pH}$ of the absorbed solution, with each phosphate salt having a definite $\mathrm{pH}$ at which its absorption by the leaf was maximum. Sodium orthophosphate showed its maximum absorption at $\mathrm{pH}$ 5.0, while the potassium and ammonium orthophosphates 
showed their maximum absorptions at $\mathrm{pH} 3$ and 10, respectively. According to the percentage absorption values obtained the orthophosphates can be ranked as follows: $\mathrm{NH}_{4}^{+}>\mathrm{K}^{+}>\mathrm{Na}^{+}$.

TABLE 3.-Order of effectiveness of the wetting agents tested, using $\mathrm{H}_{3} \mathrm{P}^{32} \mathrm{O}_{4}, \mathrm{pHs}$, as phosphate

\begin{tabular}{|c|c|c|c|}
\hline \multirow{2}{*}{ Effectiveness } & \multicolumn{3}{|c|}{ Percentage concentration of wetting agents- } \\
\hline & 0.1 & 0.01 & 0.001 \\
\hline Most & Tergitol & Tergitol & Atlox 210 \\
\hline Do. & Sterox & Sterox & Tergitol \\
\hline Do. & $\begin{array}{l}\text { Agricultural surfac- } \\
\text { tant }\end{array}$ & Atlox 210 & $\begin{array}{l}\text { Agricultural surfac- } \\
\text { tant }\end{array}$ \\
\hline Do. & Atlox 210 & $\begin{array}{l}\text { Agricultural surfac- } \\
\text { tant }\end{array}$ & Sterox \\
\hline Do. & Triton $\mathrm{X}-400$ & Triton & Triton \\
\hline Do. & Atlox 209 & Glycerine & Glycerine \\
\hline Least & Glycerine & Atlox 209 & Atlox 209 \\
\hline
\end{tabular}

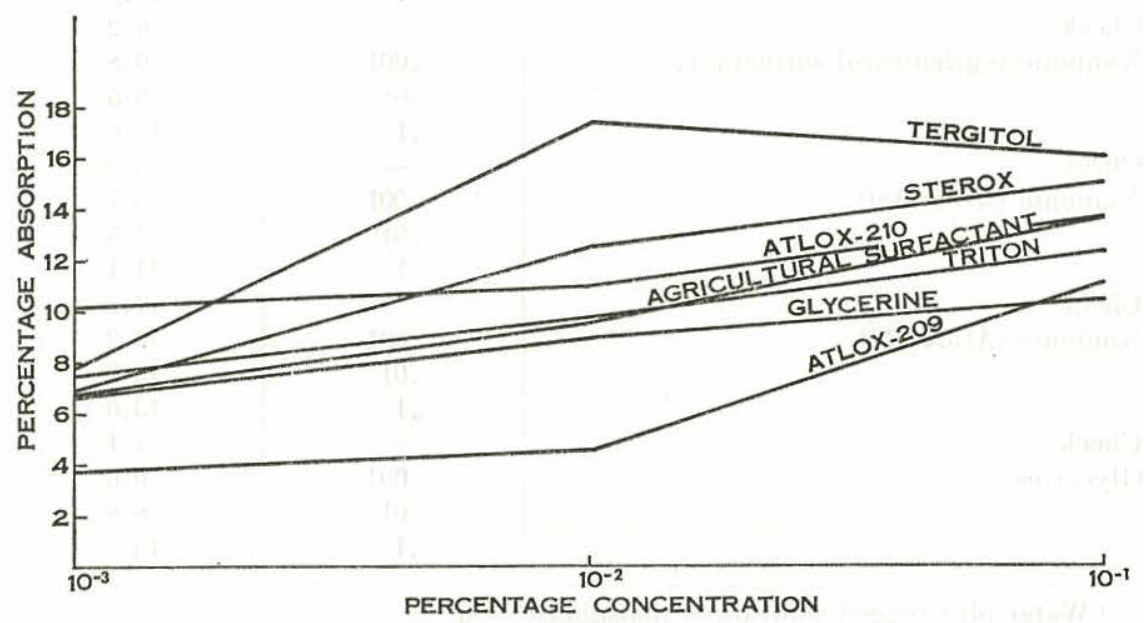

FIG. 1.-Concentration of wetting agents plotted against extent absorption of $\mathrm{P}^{32}$ by sugarcane leaves.

The time required for 50-percent absorption of the foliar-applied potassium orthophosphate was studied using three different wetting agents, cationic, anionic, and nonionic (Triton X-400, Tergitol 7, and Sterox AJ-100 respectively). A 0.1-M. solution of potassium orthophosphate containing 0.1 percent of the wetting agent at a $\mathrm{pH}$ of 3 , was utilized throughout the studies. The results are presented in table 5. Although the three types of 
wetting agents enhanced the absorption of foliar-applied phosphorus as compared with the control it was the anionic type which caused the greatest absorption.

Figure 2 indicates that absorption in all cases is time-dependant, i.e., the more time the applied solution is in contact with the leaf the higher

TABLE 4.-Absorption of $P^{32}$ as a function of solution $p H$ and of cation associated with the phosphate

\begin{tabular}{|c|c|c|c|c|c|}
\hline \multicolumn{2}{|c|}{$\mathrm{NaH}_{2} \mathrm{PO}_{4}$} & \multicolumn{2}{|c|}{$\mathrm{KH}_{2} \mathrm{PO}_{4}$} & \multicolumn{2}{|c|}{$\mathrm{NH}_{4} \mathrm{H}_{2} \mathrm{PO}_{4}$} \\
\hline $\mathrm{pH}$ & $\begin{array}{l}\text { Percent } \\
\text { absorption }\end{array}$ & $\mathrm{pH}$ & $\begin{array}{c}\text { Percent } \\
\text { absorption }\end{array}$ & $\mathrm{pH}$ & $\begin{array}{c}\text { Percent } \\
\text { absorption }\end{array}$ \\
\hline Check $^{1}$ & 5.8 & Check $^{1}$ & 7.4 & Check $^{1}$ & 8.4 \\
\hline 4 & 19.4 & 2 & 25.2 & 9 & 25.4 \\
\hline 5 & 24.2 & 3 & 26.4 & 10 & 26.6 \\
\hline 6 & 16.9 & 4 & 17.8 & 11 & 24.3 \\
\hline
\end{tabular}

${ }^{1}$ Checks were solution of phosphate salt without wetting agent. All other solutions contained Tergitol 7 at 0.1 -percent concentration.

TABLE 5.-Absorption rate of potassium orthophosphate in 0.1-percent solution of wetting agents

\begin{tabular}{l|c|r|r|r|r|r}
\hline \multirow{2}{*}{$\begin{array}{c}\text { Commercial name of wetting } \\
\text { agent }\end{array}$} & \multicolumn{2}{|c|}{ Type } & \multicolumn{1}{|c}{$\begin{array}{c}\text { Percentage phosphorus absorption after time elapsed } \\
\text { (days) }\end{array}$} \\
\cline { 3 - 7 } & & 2 & 6 & 10 & 14 & 18 \\
\hline Water & - & 3.4 & 5.5 & 8.7 & 13.3 & 16.0 \\
Triton X-400 & Cationic & 24.4 & 32.4 & 35.2 & 37.1 & 43.4 \\
Sterox AJ-100 & Nonionic & 23.2 & 30.0 & 39.5 & 43.2 & 46.5 \\
Tergitol Anionic 7 & Anionic & 28.5 & 36.9 & 42.2 & 46.2 & 49.9 \\
\hline
\end{tabular}

is the percentage absorption. The graph also shows that the time required for 50-percent absorption of potassium orthophosphate in presence of Tergitol, and applied to the leaf of 1-month-old sugarcane, is 18 days.

\section{SUMMARY}

The effect of wetting agents at three different concentrations upon the absorption of foliar-applied phosphates was studied. A concentration of 0.1 percent of the wetting agent proved to be the best to work with, for it gave the maximum phosphate absorption in all cases. The order of their effectiveness, as measured by the ability to enhance phosphorus absorption by the leaf was as follows: Tergitol $7>$ Sterox AJ-100 $>$ Agricultural surfactant $>$ Atlox $210>$ Triton X-400 > Atlox $209>$ Glycerine. Both 
Tergitol and Sterox AJ-100 increased in phosphorus absorption while glycerine caused a reduction in absorption when applied as sprays $(14,19)$.

The maximum absorption by sugarcane leaves of foliar-applied orthophosphates of sodium, potassium, and ammonium was found to occur at $\mathrm{pH}$ 's 5,3 , and 10, respectively. As pointed out in the literature (19) phosphate absorption varies with the accompanying cation, the $\mathrm{pH}$ of the applied solution and the time the applied solution is in contact with the leaf. The time required for 50-percent absorption of potassium orthophosphate by the leaf of a 1-month-old sugarcane plant was 18 days.

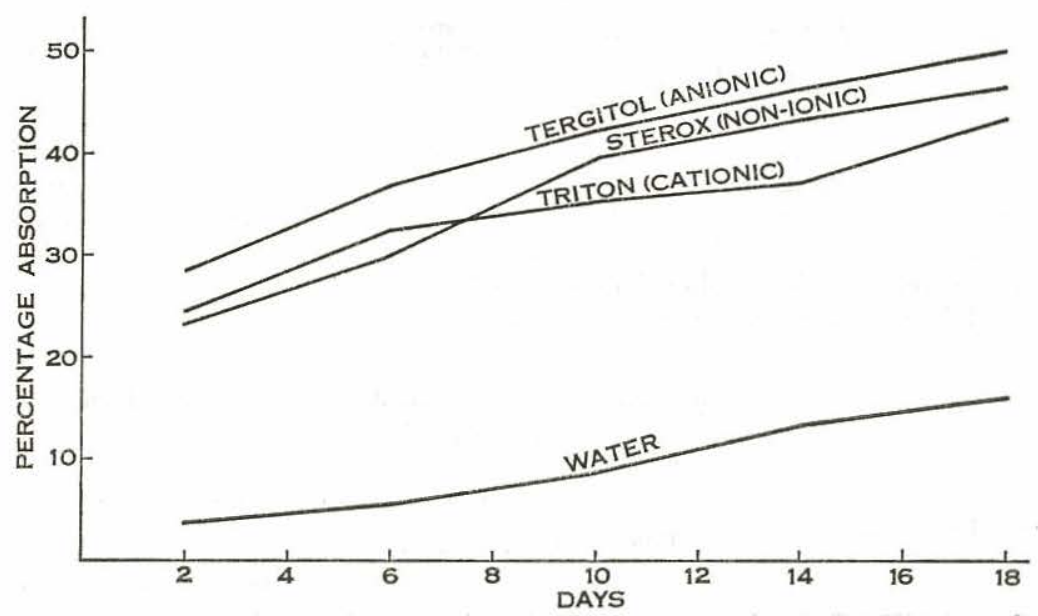

FIg. 2.-Comparative absorption rate by sugarcane leaves of $\mathrm{KH}_{2} \mathrm{PO}_{4}$ in $1 / 10$-percent solution of 3 different wetting agents.

Burr et al. (8) report 15 days as the comparative absorption rate for sugarcane.

\section{RESUMEN}

Se estudió el efecto de agentes humectantes, a tres concentraciones distintas, sobre la absorción de fosfatos aplicados foliarmente. La concentración de 0.1 por ciento del agente humectante probó ser la mejor para trabajar, porque inducía la máxima absorción del fosfato en todos los casos. El orden de la eficacia de los agentes humectantes, según su habilidad para aumentar la absorción del fósforo por la planta, fue como sigue: Tergitol $7>$ Sterox AJ-10 > Agricultural Surfactant > Atlox $210>$ Triton X-400 > Atlox $209>$ Glycerine. Tanto el Tergitol como el Sterox A-J 100 causan aumentos en la absorción de fósforo, mientras que la glicerina reduce la absorción cuando se asperjó sobre las hojas $(14,19)$.

La absorción máxima de los ortofosfatos de sodio, potasio y amonio, 
aplicados foliarmente, se encontró que ocurrió en los niveles de $\mathrm{pH} 5$, 3 y 10, respectivamente. Según los eñala la literatura (19), la absorción del fosfato varía con el catión acompañante, el pH de la solución aplicada y el tiempo en que la solución que se aplique esté en contacto con la joja. El tiempo requerido para obtener un 50 por ciento de absorción del ortofosfato de potasio por la hoja en una planta de caña de azúcar de 1 mes de sembrada fue 18 días. Burr et al. (8) informaron que la razón de absorción comparativa para la caña de azúcar es de 15 días.

\section{LITERATURE CITED}

1. Ahlgren, G. E., and Sudia, T. W., The distribution of foliarly applied $\mathrm{P}^{32}$ from the leaves of soybeans, Proc. Annual Meetings; Plant Physiology 37: 11-12, 1962.

2. Babcock, K. L., Radioisotopes in trace-element studies in soil and plants, Int. J. Appl. Radiat. and Isotopes xi-xii, 13: 353-8, 1962.

3. Baldacci, E., Foa, R., and Volpi, A., Absorption and transfer of phosphorus in healthy and diseased plants, Proc. 2nd. U.N. Int. Conf. on the Peaceful Uses of Atomic Energy, Geneva 27: 37-41, 1958.

4. Boroughs, H., Bornemisza, E., and Da Silva Cardozo, A., The foliar absorption by cacao of $\mathrm{P}^{32}$ labelled sodium, potassium and ammonium phosphate as influenced by $\mathrm{pH}$, Plant and Soil xix(2): 241-8, 1963.

5. Boroughs, H., and Labarca, C., The use of wetting agents in foliar nutrition, Int. J. of Appl. Radiat. and Isotopes 13: 358-64, 1962.

6. Boynton, D., Nutrition by foliar application, Ann. Rev. Plant Physiol. 5: 31-54, 1954.

7. Bukovac, M. J., and Wittwer, A. H., Absorption and mobility of foliar applied nutrients, Plant Physiol. 32: 428-35, 1957.

8. Burr, G. O., Payne, J. H., Silva, J. A., and Sloane, E. C., Use of radioisotopes by Hawaiian Sugar Plantation, Int. Conf. on Peaceful use of Atomic Energy, Geneva, Switzerland, 12: 177-183, 1956.

9. Burr, G. O., The use of radioisotopes by the Hawaiian Sugar Plantation, Int. J. of Appl. Radiat. and Isotopes 13: 365-374, 1962.

10. Cain, J. C., Absorption and metabolism of urea by leaves of coffee, cacao and banana, Proc. Amer. Soc. Hort. Sci. 67: 279-86, 1956.

11. Colwell, R. N., The use of radioactive phosphorus in translocation studies, Am. J. Bot. 29: 798-801, 1942.

12. Dean Dubing, C., and Currier, H. B., Foliar penetration by chemicals, Plant Physiol. 36: 169-174, 1961.

13. Dutt, A. K., Sulfur deficiency in sugarcane, Emp.J. Exp. Agr. 30: 257-262, 1962.

14. Fisher, E. G., and Walker, D. R., The apparent absorption of phosphorus and magnesium from sprays applied to the lower surface of McIntosh apple leaves, Proc. Am. Soc. Hort. Sci. 65: 17-24, 1955.

15. Hamence, J. H., and Oram, P. A., Effects of soil and foliar applications of sodium borate to sugar beet, J. Sci. Food and Agr. 15: 565-73, 1964.

16. Klechkovski, V. M., Int. Conf. on the Peaceful Use of Atomic Energy, Geneva, Switzerland, 12: 138-43, 1955.

17. Koonz, H., and Biddulph, O., Factors affecting absorption and translocation of foliar applied phosphorus, Plant Physiol. 32: 463-470, 1957.

18. Siegel, O., and Goerke, W., The uptake of zinc and strontium in Vitis vinifera 
Int. Conf. on the Peaceful Use of Atomic Energy, Geneva, Switzerland, 27: 13, 1958.

19. Teubner, F. G., Wittwer, S. H., Long, W. C., and Tukey, H. B., Some factors affecting absorption and transport of foliar applied nutrients as revealed by radioactive isotopes, Quart. Bul., Mich. State Univ. Agr. Exp. Sta., 39: 398-415, 1957.

20. Tukey, H. B., Wittwer, S. H., Toubner, F. G., and Long, W. G., Studies of special problems in agriculture and silviculture by the use of radioisotopes, Int. Conf. on the Peaceful Use of Atomic Energy, 12: 75-81, 1955.

21. Yung, J., and Wittwer, S. H., Kinetics of foliar absorption; Proc. of the Plant Physiol. Meeting, Amherst, Mass., 38: 26, 1963. 